\title{
Intelijen Kejaksaan Perspektif Ketatanegaraan Indonesia dan Ketatanegaraan Islam
}

\section{Tegar Mawang Ditha, Dian Ekawaty Ismail, Lusiana M. Tijow}

Kejaksaan Negeri Gorontalo Utara; Universitas Negeri Gorontalo; Universitas Negeri Gorontalo

Email: tegarchenko@yahoo.co.id; dian.ekawaty23@gmail.com;

Lusianamtijow@gmail.com

\begin{abstract}
This article discusses the existence of prosecutorial intelligence which is reviewed in terms of the Indonesian constitutional structure and the Islamic state administration. This problem will be answered methodologically by using normative legal research, namely reviewing literature, laws and regulations and court decisions relating to the object of research. Based on the research results, the role of intelligence in Islamic history was an important factor in the movement to maintain the glory of Islam led by Muhammad. to fight the enemy of Islam. Intelligence activities get recognition from the content of several verses in the Koran as a way to practice amar ma'ruf nahi munkar. Meanwhile in the state administration in Indonesia, the prosecutor's intelligence activities as state intelligence administrators have an important role in maintaining state security and order in groups or individuals who want to destroy the order of life as a nation and state.
\end{abstract}

Keywords: Attorney Intelligence, State Administration

\section{Intelligence of the Prosecutor's Office in the Indonesian Constitutional and Islamic Constitution Perspectives}

\begin{abstract}
Abstrak: Artikel ini membahas eksistensi intelijen kejaksaan yang dikaji dari segi struktur ketatanegaraan Indonesia dan ketetanegaraan Islam. Permasalahan tersebut akan dijawab secara metodologis dengan menggunakan penelitian hukum normatif (normative legal research), yaitu mengkaji literatur, peraturan perundang-undangan dan putusan-putusan pengadilan yang berhubungan dengan objek penelitian. Berdasarkan hasil penelitian bahwa peran intelijen dalam sejarah Islam menjadi faktor penting dalam pergerakan untuk mempertahankan kejayaan Islam yang dipimpin oleh Muhammad saw. untuk melawan musuh Islam. Aktivitas intelijen mendapatkan pengakuan dari kandungan beberapa ayat dalam Alquran sebagai jalan untuk bagaimana mengamalkan amar ma'ruf nahi munkar. Sedangkan dalam ketatanegaraan di Indonesia, aktivitas intelijen kejaksaan sebagai penyelenggara intelijen negara memiliki peran penting dalam menjaga keamanan dan ketertiban negara dalam kelompok atau individu yang ingin merusak tatanan kehidupan berbangsa dan bernegara.
\end{abstract}

Kata Kunci: Intelijen Kejaksaan, Ketatanegaraan 
Intelijen Kejaksaan Perspektif Ketatanegaraan Indonesia dan Ketatanegaraan Islam

\section{A. Pendahuluan}

Sejarah perjuangan Republik Indonesia membuktikan bahwa dalam membela dan mempertahankan kemerdekaan dan kedaulatannya, bangsa Indonesia menumbuhkan kesadaran akan perlunya Intelijen yang tangguh untuk menjaga berbagai rongrongan baik dari dalam maupun dari luar negeri. Aktivitas intelijen pada saat-saat menjelang dan setelah proklamasi kemerdekaan Indonesia maupun perkembangannya selama perang kemerdekaan menunjukkan bahwa memang telah terbentuk badan-badan intelijen yang terus bertumbuh sejalan dengan kebutuhan maupun perkembangan situasi dan kondisi negara yang relatif masih muda dimasa itu. ${ }^{1}$

Patut dicatat bahwa badan-badan intelijen dimaksud berjuang tanpa pamrih, dan tidak pernah surut dalam pengabdiannya untuk membela kepentingan maupun keselamatan bangsa dan Negara. Perkembangan badan-badan intelijen dimulai dengan adanya Badan Istimewa, yang dipimpin oleh Zulkifli Lubis yang didalamnya ada bagian yang disebut Penyelidik Militer Khusus (PMC), dengan titik berat tugas intelijen tempur. Badan istimewa ini merupakan bagian dari Badan Keamanan Rakyat (BKR). Pada 7 Mei 1946 Presiden Republik Indonesia secara resmi membentuk badan intelijen yang disebut Badan Rahasia Negara Indonesia (BRANI), dipimpin oleh Kolonel Zulkifli Lubis, dengan bagian yang disebut Field Preparation (FP), dengan tugas diperluas dari intelijen tempur menjadi intelijen strategis. Pada tahun 1947 BRANI dibubarkan. Intelijen negara diselenggarakan oleh Kementerian Pertahanan dalam hal ini BAGIAN V (KP-V), dipimpin Letkol Laut Abdurrahman. BAGIAN V (KP-V) Kementerian Pertahanan, dibubarkan, selanjutnya dibentuk Intelijen Kementerian Pertahanan (IKP), yang didalamnya ada BISAP (Biro Informasi Staf Angkatan Perang), yang dipimpin oleh Kolonel Zulkifli Lubis. Setelah peristiwa 17 Oktober 1952 IKP dibubarkan, dengan demikian mulai saat itu tidak ada badan yang menyelenggarakan intelijen negara. ${ }^{2}$

Pada tahun 1958 berdasarkan Peraturan Pemerintah Nomor 64/1958 tanggal 5 Desember 1958 (Lembaran Negara Nomor 150/1958) ditetapkan berdirinya Badan

\footnotetext{
${ }^{1}$ Naskah Akademik Rancangan Undang-Undang Republik Indonesia tentang Intelijen Negara, 3, http://lama.elsam.or.id, diakses pada tanggal 10 Maret 2020.

${ }^{2}$ Ibid., 4.
} 
Koordinasi Intelijen (BKI), yang dipimpin oleh Kolonel Laut Pirngadi. Anggota BKI terdiri dari wakil-wakil badan intelijen sipil dan militer, antara lain dari Kejaksaan Agung, Jawatan Kepolisian Negara, Badan-badan Intelijen Angkatan, wakil-wakil instansi yang dianggap perlu. Pada tahun 1959 diganti dengan Badan Pusat Intelijen (BPI), dipimpin oleh Soebandrio. Setelah peristiwa G.30.S/PKI, pada tahun 1966 BPI dibubarkan dan diganti dengan Komando Intelijen Negara (KIN), dengan Letjen Soeharto sebagai Panglima KIN. Selanjutnya pada tahun 1967 setelah Letjen Soeharto sebagai Pjs. Presiden, KIN dirubah menjadi Badan Koordinasi Intelijen Negara (BAKIN), dengan Mayjen Soedirgo sebagai Kepala BAKIN. Pada tahun 2000, setelah reformasi BAKIN diganti menjadi Badan Intelijen Negara (BIN) hingga saat ini. ${ }^{3}$

Jauh sebelum Indonesia merdeka, sejarah perjuangan dakwah Baginda Nabi Muhammad SAW sangat berat dalam mensyiarkan agama islam ke seluruh jazirah wilayah mekkah dan madinah. Tantangan terbesar Rasulullah mendakwahkan Islam adalah sejak wahyu pertama yang turun pada 17 Ramadhan 13 tahun sebelum hijrah. Firman Allah ketika itu adalah seruan kepada umat manusia untuk membaca atas nama-Nya. Ini adalah perintah Sang Pencipta untuk tunduk dan patuh kepada-Nya dengan mengakui tiada tuhan selain Allah dan Muhammad adalah Rasulullah.

Nama-nama seperti Khadijah sang istri Rasulullah saw., Ali bin Abi Thalib sepupunya, dan para sahabat lainnya adalah orang-orang terdekat beliau yang diajak untuk memeluk Islam secara diam-diam. Belasan orang yang disebut assabiqunal awwalunini kemudian membantu menyebarkan Islam secara diam-diam. Rasulullah tak ingin dakwahnya menimbulkan kegaduhan sehingga memunculkan perlawanan yang mengakibatkan kegagalan. Inilah dakwah klandestin (secara rahasia) yang masuk ke dalam kehidupan masyarakat Arab yang kemudian mengubah kehidupan dunia. Dakwah seperti itu merupakan gaya intelijen klasik yang di dalamnya ada unsur, yaitu:

1) Penghimpunan jejaring secara rahasia, yaitu dakwah Nabi saw. kepada assabiqunal awwalun. $^{4}$

\footnotetext{
${ }^{3}$ Ibid., 5.

${ }^{4}$ Assabiqunal awwalun adalah orang-orang terdahulu yang pertama kali masuk/memeluk Islam. Mereka dari golongan kaum Muhajirin dan Anshar, https://id.wikipedia.org/wiki/Pemeluk_Islam_ pertama, diakses pada tanggal 12 April 2020.
} 
Intelijen Kejaksaan Perspektif Ketatanegaraan Indonesia dan Ketatanegaraan Islam

2) Analisis, bentuk interaksi Nabi dengan para sahabat untuk mencermati keadaan.

3) Konter intelijen, penanggulangan serangan kaum jahiliyah yang menganggap Islam bertentangan dengan tradisi yang sudah ada. Ini terjadi setelah masa dakwah siri dan

4) Operasi senyap, membawa Nabi secara rahasia dari Makkah ke Madinah. ${ }^{5}$

Intelijen pada tataran praksis berperan sebagai garda terdepan dalam sistem keamanan nasional. Ketentuan Undang-Undang Nomor 17 Tahun 2011 tentang Intelijen Negara ${ }^{6}$ yang menjadi payung hukum bagi penyelenggara intelijen dalam menjalankan tugas dan fungsi intelijen, dimana hakikat intelijen negara merupakan lini pertama dalam sistem keamanan nasional. Artinya bahwa cara kerja intelijen sebagai garda terdepan dalam sistem keamanan nasional berperan untuk melakukan deteksi dini serta peringatan dini terhadap gangguan atau ancaman terhadap keamanan nasional, agar dapat diambil suatu kebijakan oleh pemerintah, untuk menghindari atau mengatasi ancaman ini. Dalam batas penalaran yang wajar bahwa memang intelijen negara bertujuan untuk mendeteksi, mengindentifikasi, menilai, menganalisa, menafsirkan dan menyajikan informasi intelijen, dalam rangka memberikan peringatan dini untuk mengantisipasi berbagai kemungkinan bentuk dan sifat ancaman yang potensial dan nyata, dalam upaya mendukung policy maker mencapai tujuan nasional dan keamanan nasional.

Era revolusi industri 4.0 sangat mempengaruhi pola dan bentuk ancaman. Ancaman kedaulatan negara tidak lagi bersifat fisik belaka atau hal-hal yang konvensional, justru ancaman yang nyata berkembang menjadi multidimensional (fisik dan non fisik), baik yang berasal dari luar negeri maupun dari dalam negeri. Ancaman itu berakar pada permasalahan ideologi, politik, ekonomi, sosial budaya maupun permasalahan keamanan yang terkait dengan kejahatan transnasional. pada titik ini dibutuhkan peran intelijen untuk mendeteksi ancaman sejak dini guna menjaga stabilitas keamanan nasional.

\footnotetext{
${ }^{5}$ Operasi Intelijen Rasulullah, https:/www.republika.co.id/berita/dunia-islam/islam-digest/18/02/26/ p4quuz313-operasi-intelijen-rasulullah, diakses pada tanggal 1 April 2020.

${ }^{6}$ Lihat Republik Indonesia, Undang-Undang Nomor 17 Tahun 2011 tentang Intelijen Negara.
} 
Perkembangan intelijen negara juga bergantung pada informasi yang dapat dijadikan policy oleh Presiden sebagai kepala negara dan kepala pemerintahan untuk menunjang jalannya suatu pemerintahan negara dan terjaminnya keamanan negara yang kondusif. Sebab UUD NRI Tahun 1945 telah melandasi kewenangan Presiden untuk berperan sebagai eksekutor dalam menindalanjuti informasi intelijen dalam rangka menjaga keamanan negara. Ketentuan Pasal 4 UUD NRI Tahun 1945 disebutkan bahwa "Presiden Republik Indonesia memegang kekuasaan pemerintahan menurut Undang-Undang Dasar"7 telah menjadi landasan konstitusional Presiden untuk menentukan informasi yang didapati melalui kerja-kerja intelijen mampu dijadikan rujukan untuk membuat sebuah kebijakan strategis dalam sistem ketatanegaraan Indonesia. Selain itu, Amanat alinea keempat UUD NRI Tahun 1945 sudah sangat jelas menerangkan bahwa pemerintahan negara Rebuplik Indonesia berkewajiban untuk melindungi bangsa dan seluruh tumpah darah Indonesia, memajukan kesejahteraan umum, mencerdaskan kehidupan bangsa, dan ikut melaksanakan ketertiban dunia yang berdasarkan kemerdekaan, perdamaian abadi, dan keadilan sosial.

Sesuai Pasal 4 UU Nomor 17 Tahun 2011 tentang Intelijen Negara bahwa Intelijen Negara berperan melakukan upaya, pekerjaan, kegiatan, dan tindakan untuk deteksi dini dan peringatan dini dalam rangka pencegahan, penangkalan, dan penanggulangan terhadap setiap hakikat Ancaman yang mungkin timbul dan mengancam kepentingan dan keamanan nasional. Menurut Shulsky dan Schmith sebagaimana dikutip oleh Ikrar Nusa Bakti, bahwa pada tataran operasional terdapat empat hakikat intelijen, yaitu;

1) Bagian dari sistem keamanan nasional;

2) Sistem peringatan dini;

3) Sistem manajemen informasi;

4) Sistem analisis strategis, dimana tujuannya adalah untuk mencegah terjadinya pendadakan startegis (strategic suprises) di bidang keamanan nasional dan

${ }^{7}$ Republik Indonesia, Undang-Undang Dasar Negara Republik Indonesia Tahun 1945 Pasca Amandemen, Pasal 4. 
Intelijen Kejaksaan Perspektif Ketatanegaraan Indonesia dan Ketatanegaraan Islam

melindungi keutuhan dan keberlangsungan negara berdasarkan prinsip negara demokratis. ${ }^{8}$

Pemikiran Shulsky dan Schmitt ini dapat ditarik suatu benang merah, bahwa hakekat intelijen adalah melindungi kebutuhan dan kelestarian negara berdasarkan prinsip negara demokratis dengan membentuk sistem peringatan dini dan sistem analisa strategis untuk mencegah pendadakan strategis di bidang keamanan nasional. ${ }^{9}$ Alquran telah menjelaskan bahwa pentingnya untuk menjaga keamanan nasional dari serangan musuh yang terselubung, yaitu:

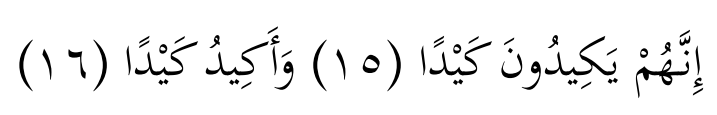

Terjemahnya:

Sungguh, mereka (orang kafir) merencanakan tipu daya yang jahat, dan Aku pun membuat rencana (tipu daya) yang jitu (QS. al-Ṭāriq/86: 15-16). ${ }^{10}$

Momentum perang intelijen saat perang badar menjadi sejarah peradaban intelijen di masa Rasulullah saw., bahkan beliau sendiri ikut ambil bagian dalam aktivitas ini. ${ }^{11}$ Aktivitas intelijen ketika menghadapi perang Badar, yaitu Rasulullah saw. mampu menyembunyikan identitas yang sebenarnya menjadi strategi penting dalam melakukan penjaringan informasi dari kubu lawan, sehingga pada saat musuh

\footnotetext{
${ }^{8}$ Ikrar Nusa Bhakti, Intelijen dan Keamanan Negara: Reformasi Intelijen Negara (Jakarta: Pacivis UI dan FES, 2005), 4.

${ }^{9}$ Ali Abdullah Wibisono dan Faisal Idris, Menguak Intelijen "Hitam" Indonesia (Jakarta: Pacivis University of Indonesia, 2006), 14.

${ }^{10}$ Kementerian Agama RI. Ummul Mukminin: Al-Qur'an dan Terjemahan untuk Wanita (Jakarta: Penerbit Wali, 2010), 591.

${ }^{11}$ Pada saat Rasulullah bertolak dari Desa Dafiran, untuk melakukan perjalanan menuju sebuah tempat dekat Badar. Di tempat itu, beliau bertemu dengar seorang laki-laki tua yang tinggal di pedalaman gurun (Badui). Rasulullah saw. lalu bertanya perihal kedatangan kaum Quraisy, juga kedatangan pasukan beliau sendiri. Lelaki itu menolak memberikan informasi, kecuali setelah beliau berdua membuka identitas. Rasulullah saw. tidak menyerah dengan jawaban itu hingga akhirnya lelaki tua itu membuka mulut dan memberikan informasi penting tentang kaum Quraisy. Informasi yang diberikan laki-laki tua itu amatlah berharga bagi umat Islam, karena dengan mengetahui kondisi musuh, maka pasukan Islam memiliki persiapan lebih matang dan informasi itu bisa dijadikan pijakan dalam menentukan strategi bertempur. Bahkan lebih dari itu, walau mendapat informasi lengkap, karahasiaan identitas kaum Muslimin tetap terjaga. Ini bisa terwujud karena Rasulullah saw. menyembunyikan identitas. Maka pihak Quraisy pun tidak bisa mengorek keterangan dari laki-laki Badui tersebut mengenai kondisi pasukan Muslimin. Lihat https://www.arrahmah.com/konsep-intelijen-rasulullah/, diakses pada tanggal 12 April 2020.
} 
menyerang, rasulullah sudah punya gambaran peta kekuatan yang dimiliki oleh kaum Quraisy. Rasulullah saw. amat memperhatikan pentingnya aktivitas ini guna melawan kekuatan Quraisy.

Kedudukan intelijen di dalam UUD NRI Tahun 1945, yaitu intelijen merupakan institusi sipil (dengan pengecualian intelijen militer) yang menjadi bagian integral dari sistem keamanan nasional, yang memiliki kompetensi utama dalam melakukan kegiatan-kegiatan intelijen dalam rangka pengembangan sistem peringatan dini dan sistem analisa strategis. ${ }^{12}$ Hakekat intelijen dalam sistem ketatanegaran indonesia belum terlembagakan dengan baik sehingga dari segi regulasi sering mengalami tumpang tindih. Menurut Wibisono bahwa intelijen negara sebagai lembaga pemerintah yang merupakan bagian dari sistem keamanan nasional yang berwenang melakukan aktivitas intelijen. Intelijen didefinisikan sebagai segala upaya mengembangkan sistem deteksi dan peringatan dini dalam rangka pencegahan, penangkalan, dan penanggulangan ancaman keamanan nasional. Selain tidak menegaskan karakter sipil yang semestinya muncul pada pemahaman hakikat intelijen, pemahaman tentang hakekat intelijen ini masih terlalu luas, sehingga belum bisa menjawab posisi ketatanegaraan lembaga intelijen di Indonesia dan peran apa yang dilayani oleh lembaga intelijen di posisi tersebut.

Regulasi intelijen negara harus memperlihatkan hakekat intelijen sebagai institusi sipil yang menjadi bagian dari kekuasaan eksekutif unt uk menjamin keamanan nasional. Dengan pemahaman hakekat seperti ini diharapkan hubungan antara lembaga intelijen dan penguasa eksekutif yang mengarah pada pelanggengan rezim dapat dicegah. Adapun penegasan karakter sipil dari institusi intelijen tidak hanya dimaksudkan untuk mencegah perwira-perwira aktif militer untuk menempati lembaga intelijen, tetapi untuk menjaga kepatuhannya terhadap pemenuhan hak-hak dasar warga negara. ${ }^{13}$

\footnotetext{
${ }^{12}$ Kelompok Kerja Indonesia Untuk Reformasi Intelijen Negara, Rancangan Undang-Undang Intelijen Negara (Jakarta: Pacivis-Departemen Hubungan Internasional, Fakultas Ilmu Sosial dan Politik, Universitas Indonesia, 2005). Tim ini beranggotakan Aleksius Jemadu, Andi Widjajanto, Cornelis Lay, Edy Prasetyono, Fajrul Falaakh, Hariyadi Wirawan, Ikrar Nusa Bhakti, Kusnanto Anggoro, Makmur Keliat, dan Rudy Satrio Mukantardjo.

${ }^{13}$ Ali Abdullah Wibisono, Reformasi Intelijen dan Badan Intelijen Negara (Jakarta: IDSPS Press, 2009), 20.
} 
Intelijen Kejaksaan Perspektif Ketatanegaraan Indonesia dan Ketatanegaraan Islam

Ketentuan Undang-Undang Nomor 17 Tahun 2011 tentang Intelijen Negaramenegaskan bahwa ruang lingkup Intelijen Negara meliputi Intelijen dalam negeri dan luar negeri, Intelijen pertahanan dan/atau militer, Intelijen kepolisian, Intelijen penegakan hukum dan Intelijen kementerian/lembaga pemerintah nonkementerian. ${ }^{14}$ Oleh karena itu, dari kelima ruang lingkup tersebut, intelijen penegakan hukum yang menjadi objek kajian dalam artikel adalah mencermati pelaksana fungsi intelijen dalam penegakan hukum, yaitu intelijen kejaksaan yang merupakan instrumen negara dalam mencegah tindakan yang berpotensi terjadinya pelanggaran hukum pidana dan gangguan terhadap ketertiban dan ketentraman masyarakat.

\section{B. Intelijen Kejaksaan sebagai Penyelenggara Intelijen Negara}

Kata Intelijen berasal dari Bahasa Inggris, yaitu intelligent dan inteligance. Dalam kamus bahasa inggris indonesia, intelligent berarti cerdas, sedangkan intelligence berarti kecerdasan, kabar, berita. ${ }^{15}$ Sedangkan dalam Kamus Hukum bahwa Intelijen merupakan kegiatan mata-mata atau spionase yang dilakukan suatu negara untuk memperoleh data rahasia negara mengenai informasi di bidang militer, teknologi, politik, ekonomi, sosial dan budaya, sehingga peta kekuatan atau aktivitas dan rencana musuh dapat diketahui. Sebaliknya, kontra-intelijen berusaha untuk

\footnotetext{
${ }^{14}$ Kehadiran Undang-Undang Nomor 17 tahun 2011 belum sepenuhnya sempurna dalam kaitannya dengan mekanisme pengawasan yang bisa dilakukan terhadap institusi intelijen di Indonesia. Beberapa problematika yang muncul terkait dengan pengawasan intelijen adalah; Pertama, tidak secara nasional secara rigid dan jelas menidifinisikan apa itu keamanan nasional. Definisi yang jelas tentang keamanan nasional dapat menjadi instrumen atas batas-batas kerja institusi dan jenis pekerjaaan intelijen yang dilakukan dan menghindarkan penyalahgunaaan kewenangan istimewa yang dimiliki oleh badan-badan intelijen dalam praktek sehari-hari dimana tidak ada suatu ancaman nyata terhadap negara. Kedua, pembagian kewenangan pada badan-badan intelijen yang ada tidak dibarengi dengan pembagian kompetensi dan tingkatan penindakan pada masing-masing penyelenggara intelijen yang ada sehingga dimungkinkan terjadinya tumpang tindih kegiatan dan operasi atas penyelenggara intelijen yang satu dengan lainnya. Ketiga, tidak secara detil merinci pengawasan eksternal terutama yang terkait dengan intelijen kementerian. Pengawasan eksternal hanya muncul dalam satu klausul tentang pembentukan komite pengawas intelijen oleh DPR. Mekanisme kontrol anggaran juga belum ada karena dalam masalah anggaran hanya dimuat klausul tentang sumber dana badan intelijen saja. Lihat Ikrar Nusa Bhakti dan Diandra Megaputri Mengko, "Intelijen Dalam Pusaran Demokrasi Di Indonesia Pasca Orde Baru," Jurnal Penelitian Politik, Volume 13 No. 1 Juni 2016; 78.

${ }^{15}$ S. Wojowasito dan W. J. S. Poerwadarminta, Kamus Bahasa Inggris Indonesia (Hasta: Bandung, 2007), 88.
} 
menemukan agen-agen spionase yang menjalankan kegiatan mata-mata untuk negara lain". 16

Menurut Manulang bahwa istilah intelijen dibagi menjadi beberapa pengertian diantaranya: Pertama, intelijen merupakan science (pengetahuan); Kedua, intelijen merupakan pengumpulan unsur-unsur utama dalam sebuah informasi, selanjutnya diolah menjadi informasi analisis; Ketiga, intelijen merupakan organisasi atau institusi mengolah informasi; Keempat. intelijen ialah informasi yang benar dan berpengaruh yang telah melalui proses evaluasi; dan Kelima, intelijen ialah berbagai cara yang digunakan untuk pengumpulan informasi. ${ }^{17}$ Selanjutnya Hendropriyono mengatakan bahwa kecepatan dan ketepatan (velox et exactus) adalah semboyan intelijen. Kecepatan dan ketepatan diperlukan dalam mengakses berbagai kemungkinan cara bertindak, yang meliputi fungsi penyelidikan (detection), pengamanan (security), baik melalui kamuflase dan kontra intelijen, atau penggalangan (conditioning) melalui perang psikologis atau perang urat syaraf. ${ }^{18}$

Tujuan intelijen negara adalah mendeteksi, mengidentifikasi, menilai, menganalisis, menafsirkan, dan menyajikan Intelijen dalam rangka memberikan peringatan dini untuk mengantisipasi berbagai kemungkinan bentuk dan sifat Ancaman yang potensial dan nyata terhadap keselamatan dan eksistensi bangsa dan negara serta peluang yang ada bagi kepentingan dan keamanan nasional. Kegiatan-kegiatan intelijen dan/atau operasi intelijen meliputi penyelidikan (LID), pengamanan (PAM) dan penggalangan (GAL). Adapun pengertian kegiatan penyelidikan, pengamanan dan penggalangan adalah:

1) Penyelidikan (LID) adalah segala usaha, pekerjaan dan kegiatan yang dilakukan secara berencana dan terarah untuk memperoleh bahan keterangan yang dibutuhkan mengenai masalah tertentu yang setelah melalui proses pengolahan dapat digunakan untuk membuat perkirakan mengenai masalah yang dihadapi

\footnotetext{
${ }^{16}$ Soesilo Prajogo. Kamus Hukum Internasional dan Indonesia (t.tp: Wacana Inteletual, 2007), 218-219.

${ }^{17}$ A. C. Manulang, Menguak Tabu Intelijen, Teror, Motif, dan Rezim (Cet. I; Jakarta: Penerbit Panta Rhei, 2000), 4.

${ }^{18}$ A. M. Hendropriyono, Filsafat Intelijen Negara Republik Indonesia (Jakarta: PT Kompas Media Nusantara, 2013), 35.
} 
sehingga dapat ditentukan kebijaksanaan dan tindakan-tindakan dengan resiko yang diperhitungkan.

2) Pengamanan (PAM) adalah semua usaha, pekerjaan dan kegiatan serta tindakan yang bertujuan untuk mencegah dan menumpas serta menggulung setiap usaha pekerjaan, kegiatan dan operasi pihak musuh/lawan yang melakukan penyelidikan, sabotase dan penggalangan.

3) Penggalangan (GAL) adalah semua usaha, pekerjaan dan tindakan secara berencana dan terarah oleh sarana-sarana intelijen, dengan membuat tujuan khusus membuat, menciptakan dan atau mengubah suatu kondisi di daerah tertentu dalam jangka waktu tertentu yang menguntungkan dan sesuai dengan kehendak pihak atasan yang berwenang untuk mendukung kebijaksanaan yang ditempuh dan untuk menghilangkan hambatan-hambatan. ${ }^{19}$

Penyelidikan intelijen dilakukan dalam rangka upaya yang dilaksanakan secara berencana, bertahap dan berkelanjutan untuk mencari, menggali dan mengumpulkan bahan keterangan maupun data pendukung lainnya yang sumbernya dapat dipercaya melalui kegiatan operasi yang telah dilakukan. Selanjutnya bahan keterangan/data tersebut diolah dalam suatu proses sehingga menghasilkan informasi siap pakai sebagai produk intelijen, dimana produk intelijen ini akan disampaikan kepada pimpinan yang berwenang atau user terkait, yang akan digunakan sebagai bahan masukan atau pertimbangan dalam mengambil keputusan.

Pelaksanaan fungsi penyelidikan yang dilaksanakan di kejaksaan dilaksanakan oleh Seksi Intelijen yang dipimpin oleh Kepala Seksi Intelijen dengan koordinasi dan petunjuk pimpinan. Seksi Intelijen Yustisial Kejaksaan aktif untuk mendukung tegaknya supremasi hukum dan keadilan baik preventif maupun represif melaksanakan dan atau turut serta menyelenggarakan ketertiban dan ketentraman umum serta pengamanan pembangunan nasional di daerah hukum kejaksaan yang bersangkutan.

Intelijen kejaksaan dalam melakukan operasi intelijen mampu menjadikan pengintaian dan spionase sebagai salah satu usaha, kegiatan dan tindakan yang

\footnotetext{
${ }^{19}$ Togar Hutagaol, Administrasi dan Produk Intelijen Kejaksaan (Jakarta: Pusdiklat Kejaksaan Republik Indonesia, 2006), 7.
} 
dilakukan kejaksaan untuk mengungkap tindak pidana korupsi. Metode operasinya paling tidak dapat memberi dampak positif terhadap mengurangnya tindakan kejahatan yang terjadi di Indonesia.

Fungsi Kejaksaan di bidang Intelijen Yutisial dipimpin oleh Jaksa Agung Muda Intelijen yang merupakan unsur pembantu pimpinan dalam melaksanakan tugas dan wewenang di bidang Intelijen Yustisial serta bertanggungjawab langsung kepada Jaksa Agung. Intelijen Yustisial Kejaksaan adalah kegiatan dan operasi intelijen umum dengan menitikberatkan atau beraspek utama di bidang Yustisial (baik tujuan, sasaran dan landasan kegiatan) mempunyai perbedaan dengan intelijen umum hanya dalam penerapan sistem dan metodenya disesuaikan dengan sasaran tugas pokok dan fungsi intelijen dalam mendukung, mengamankan pelaksanaan tugas wewenang dan kewajiban organisasi kejaksaan.

Undang-Undang Nomor 16 Tahun 2004 tentang Kejaksaan Republik Indonesia bahwa tugas dan wewenang Kejaksaan, yaitu:

1) Di bidang pidana, kejaksaan mempunyai tugas dan wewenang:

a. Melakukan penuntutan.

b. Melaksanakan penetapan hakim dan putusan pengadilan yang telah memperoleh kekuatan hukum tetap.

c. Melakukan pengawasan terhadap pelaksanaan putusan pidana bersyarat, putusan pidana pengawasan, dan keputusan lepas bersyarat.

d. Melakukan penyidikan terhadap tindak pidana tertentu berdasarkan undangundang.

e. Melengkapi berkas perkara tertentu dan untuk itu dapat melakukan pemeriksaaan tambahan sebelum dilimpahkan ke pengadilan yang dalam pelaksanaannya dikoordinasikan dengan penyidik.

2) Dalam bidang perdata dan tata usaha negara, kejaksaan dengan kuasa khusus dapat bertindak baik di dalam maupun di luar pengadilan untuk dan atas nama negara atau pemerintah.

3) Dalam bidang ketertiban dan ketenteraman umum, kejaksaan turut menyelenggarakan kegiatan: 
a. Peningkatan kesadaran hukum masyarakat.

b. Pengamanan kebijakan penegakan hukum.

c. Pengawasan peredaran barang cetakan.

d. Pengawasan aliran kepercayaan yang dapat membahayakan masyarakat dan negara.

e. Pencegahan penyalahgunaan dan atau penodaan agama.

f. Penelitian dan pengembangan hukum serta statistik kriminal. ${ }^{20}$

Ketentuan Pasal 30 ayat (3) merupakan otoritas intelijen kejaksaan dalam melaksanakan tugas dan fungsinya dibidang ketertiban dan ketenteraman umum. Penjelasan pasal demi pasal dinyatakan bahwa tugas dan wewenang kejaksaan dalam ayat ini lebih bersifat preventif dan/atau edukatif sesuai dengan peraturan perundangundangan. ${ }^{21}$ Sedangkan yang dimaksud "turut menyelenggarakan" adalah mencakup kegiatan-kegiatan yang bersifat membantu, turut serta dan bekerjasama dengan senantiasa memperhatikan koordinasi dengan instansi terkait. ${ }^{22}$

Selanjutnya pada Pasal 15 ayat (1) Jaksa Agung Muda Bidang Intelijen mempunyai tugas dan wewenang melaksanakan tugas dan wewenang Kejaksaan di bidang intelijen Kejaksaan. ${ }^{23}$ Kemudian pada ayat (2) berbunyi lingkup bidang intelijen Kejaksaan sebagaimana dimaksud pada ayat (1) meliputi kegiatan intelijen penyelidikan, pengamanan dan penggalangan untuk melakukan pencegahan tindak pidana untuk mendukung penegakan hukum baik preventif maupun represif di bidang ideologi, politik, ekonomi, keuangan, sosial budaya, pertahanan dan keamanan, melaksanakan cegah tangkal terhadap orang-orang tertentu dan/atau turut menyelenggarakan ketertiban dan ketenteraman umum. ${ }^{24}$

\footnotetext{
${ }^{20}$ Republik Indonesia, Undang-Undang Nomor 16 Tahun 2004 tentang Kejaksaan Republik Indonesia, Pasal 30.

${ }^{21}$ Nandan Iskandar, et.al, Penguatan Peran Intelijen Kejaksaan Dalam Pengawasan Aliran Kepercayaan dan Aliran Keagamaan Dalam Masyarakat (PAKEM) Demi Ketertiban dan Ketenteraman Umum (Jakarta: Kejaksaan Agung, Pusat Penelitian dan Pengembangan, 2017), 8-10.

${ }^{22}$ Ibid., 10.

${ }^{23}$ Republik Indonesia, Undang-Undang Nomor 16 Tahun 2004 tentang Kejaksaan Republik Indonesia, Pasal 15 ayat (1).

${ }^{24}$ Ibid., Pasal 15 ayat (2).
} 
Ketentuan Pasal 16 berbunyi dalam melaksanakan tugas dan wewenang, Jaksa Agung Muda Bidang Intelijen menyelenggarakan fungsi : (a) perumusan kebijakan di bidang intelijen; (b) koordinasi dan sinkronisasi pelaksanaan kebijakan di bidang intelijen; (c) pelaksanaan hubungan kerja dengan instansi/lembaga, baik di dalam maupun di luar negeri; (d) memberikan dukungan teknis secara intelijen kepada bidang-bidang lain di lingkungan Kejaksaan; (e) pemantauan, analisis, evaluasi dan pelaporan pelaksanaan kegiatan di bidang intelijen; (f) pelaksanaan tugas lain yang diberikan oleh Jaksa Agung. ${ }^{25}$

Peraturan Jaksa Agung Republik Indonesia Nomor: Per-006/A/JA/07/2017 tentang Organisasi dan Tata Kerja Kejaksaan Republik Indonesia disebutkan tugas pokok dan fungsi intelijen kejaksaan berbunyi:

1) Jaksa Agung Muda Bidang Intelijen mempunyai tugas dan wewenang melaksanakan tugas dan wewenang Kejaksaan di bidang intelijen Kejaksaan.

2) Lingkup bidang intelijen Kejaksaan sebagaimana dimaksud pada ayat (1) meliputi kegiatan intelijen penyelidikan, pengamanan, dan penggalangan untuk melakukan pencegahan tindak pidana untuk mendukung penegakan hukum baik preventif maupun represif di bidang ideologi, politik, ekonomi, keuangan, sosial budaya, pertahanan dan keamanan, melaksanakan cegah tangkal terhadap orang tertentu dan/atau turut menyelenggarakan ketertiban dan ketenteraman umum. ${ }^{26}$

Selanjutnya pada Pasal 146 berbunyi: "Dalam melaksanakan tugas dan wewenang sebagaimana dimaksud dalam Pasal 145, Jaksa Agung Muda Bidang Intelijen menyelenggarakan fungsi: (a) perumusan kebijakan di bidang intelijen; (b) koordinasi dan sinkronisasi pelaksanaan kebijakan di bidang intelijen; (c) pelaksanaan hubungan kerja dengan instansi atau lembaga, baik di dalam maupun di luar negeri; (d) memberikan dukungan teknis secara intelijen kepada bidang lain di lingkungan Kejaksaan; (e) pemantauan, analisis, evaluasi dan pelaporan pelaksanaan kegiatan di

\footnotetext{
${ }^{25}$ Republik Indonesia, Undang-Undang Nomor 16 Tahun 2004 tentang Kejaksaan Republik Indonesia, Pasal 16.

${ }^{26}$ Peraturan Jaksa Agung Republik Indonesia Nomor: Per-006/A/JA/07/2017 tentang Organisasi dan Tata Kerja Kejaksaan Republik Indonesia, Pasal 145 ayat (1).
} 
bidang intelijen; dan (f) pelaksanaan tugas lain yang diberikan oleh Jaksa Agung." ${ }^{27}$ Kewenangan yang diberikan oleh Negara melalui peraturan perundang-undangan kepada Kejaksaan senantiasa dijadikan acuan dalam menjalankan peran dan fungsinya dalam berbagai bidang, khususnya dalam hal intelijen Negara.

\section{Kelemahan Intelijen Kejaksaan}

Kejaksaan R.I. adalah lembaga negara yang melaksanakan kekuasaan Negara khususnya di bidang penuntutan. Sebagai badan yang berwenang dalam penegakan hukum dan keadilan, kejaksaan dipimpin oleh Jaksa agung dan bertanggung jawab kepada Presiden. kejaksaan agung, kejaksaan tinggi, dan kejaksaan negeri merupakan kekuasaan negara khususnya dibidang penuntutan, dimana semuanya merupakan satu kesatuan yang utuh yang tidak dapat dipisahkan.

Pada dasarnya peran intelijen kejaksaan hanya bersifat memberikan informasi kepada user melalui jalur pimpinan dalam mendukung pelaksanaan tugas bidangbidang lain yang ada di kejaksaan seperti Pidsus, Pidum, Datun, Pengawasan dan Pembinaan. Peran intelijen kejaksaan dalam mendukung optimalisasi kinerja Kejaksaan dalam sistem peradilan pidana mempunyai peranan penting dalam mendukung kebijakan penegakan hukum dan keadilan baik preventif maupun represif, melaksanakan dan atau turut menyelenggarakan ketertiban dan ketentraman umum serta pengamanan pembangunan nasional dan hasil-hasilnya maka dilakukan kegiatankegiatan Intelijen dan atau operasi Intelijen sesuai dengan kebutuhan yang meliputi fungsi penyelidikan (LID), Pengamanan (PAM), dan Penggalangan (GAL). Adapun sasaran pelaksanaan fungsi tersebut adalah:

1) Masalah ideologi, politik, media masa, barang cetakan, orang asing, cegah tangkal, sumber daya manusia, pertahanan keamanan, tindak pidana perbatasan dan pelanggaran wilayah perairan.

2) Masalah investasi, produksi, distribusi, keuangan, perbankan, sumber daya alam, pertahanan, penanggulangan tindak pidana ekonomi serta pelanggaran zona ekonomi eksklusif.

\footnotetext{
${ }^{27}$ Ibid., Pasal 146.
} 
3) Masalah aliran kepercayaan, penyalahgunaan dan atau penodaan agama, persatuan dan kesatuan bangsa, lingkungan hidup serta penanggulangan tindak pidana umum.

Intelijen Kejaksaan sebagai bagian dari elemen penegakan hukum, dimana salah satu ruang lingkup Intelijen Negara adalah Intelijen Penegakan Hukum yang penyelenggaranya adalah Intelijen Kejaksaan. Secara institusional, intelijen kejaksaan dipimpin oleh Jaksa Agung Muda Bidang Intelijen yang bertanggung jawab langsung kepada Jaksa Agung. Pasal 15 ayat (2) PERPRES No. 29 Tahun 2016 Tentang Organisasi dan Tata Kerja Kejaksaan RI menjelaskan bahwa Jaksa Agung Muda Bidang Intelijen mempunyai tugas dan wewenang melaksanakan tugas dan wewenang kejaksaan di bidang intelijen kejaksaan yang meliputi kegiatan intelijen penyelidikan, pengamanan dan penggalangan untuk melakukan pencegahan tindak pidana untuk mendukung penegakan hukum baik preventif maupun represif di bidang ideologi, politik, ekonomi, keuangan, sosial budaya, pertahanan dan keamanan, melaksanakan cegah tangkal terhadap orang-orang tertentu dan/atau turut menyelenggarakan ketertiban dan ketenteraman umum.

Intelijen dalam proses penegakan hukum di Indonesia terbagi atas dua yaitu Intelijen yang dimiliki oleh Kepolisian Republik Indonesia dan Intelijen di lingkup Kejaksaan Republik Indonesia. Dalam upaya penegakan hukum, Intelijen Kejaksaan merupakan salah satu usaha yang dilakukan Kejaksaan untuk mengungkap kasus tindak pidana korupsi. Metode atau cara operasi Intelijen Kejaksaan diharapkan dapat mengurangi terjadinya tindak pidana korupsi di indonesia. Intelijen Kejaksaan termasuk salah satu bagian yang terdapat di dalam penyelenggraan intelijen negara. Dalam penegakan hukum tindak pidana korupsi, institusi Kejaksaan memiliki peranan yang cukup sentral. Kejaksaan tidak hanya memiliki wewenang melakukan penuntutan, dalam penanganan perkara tindak pidana khusus oleh Kejaksaan biasanya dibagi atas tahap penyelidikan, tahap penyidikan dan tahap penuntutan. ${ }^{28}$ Pada tahap penyelidikan tugas ini dilakukan oleh pihak Intelijen yang ada di setiap tahapan

\footnotetext{
${ }^{28}$ Leden Marpaung, Proses Penanganan Perkara Pidana (Di Kejaksaan \&Pengadilan Negeri Upaya Hukum dan Eksekusi) (Jakarta, Sinar Grafika, 2011), 19.
} 
Intelijen Kejaksaan Perspektif Ketatanegaraan Indonesia dan Ketatanegaraan Islam

kedudukan kejaksaan. Tahap penyidikan dilakukan oleh seksi pidana khusus yang diberikan kewenangan dalam penyidikan tindak pidana khusus, sedangkan dalam tahap penuntutan dilakukan oleh Jaksa Penuntut Umum sebagaimana diatur dalam peraturan perundang-undangan.

Permasalahannya adalah bahwa di dalam Undang-Undang Nomor 16 Tahun 2004 tentang Kejaksaan RI yang seharusnya menjadi peraturan organik dari intelijen kejaksaan tidak mengatur kedudukan dan kewenangan intelijen kejaksaan. Kondisi inilah yang menyebabkan intelijen kejaksaan belumlah kuat landasan yuridisnya yang bisa jadi menjadi penghambat intelijen kejaksaan dalam melaksanakan tugas dan fungsinya sebagai intelijen penegakan hukum. Dengan demikian permasalahan yuridis inilah yang mesti diformulasikan kembali suatu kebijakan hukum dalam mengakomodir intelijen kejaksaan dalam peraturan organiknya, yaitu Undang-Undang Nomor 16 Tahun 2004 tentang Kejaksaan RI.

Intelijen kejaksaan secara struktural dan fungsional berada dalam institusi Kejaksaan Agung RI. Jika mencermati kondisi sekarang, keberadaan intelijen di dalam institusi tersebut mengalami alineasi karena secara yuridis pengaturan intelijen kejaksaan tidak terurai secara jelas dalam undang-undang Kejaksaan Republik Indonesia, dalam artian bahwa sangat diperlukan penataan ulang dalam undang-undang Kejaksaan Republik Indonesia tersebut sebagai upaya untuk merespon kelemahan intelijen kejaksaan. Apalagi kapasitas dan kapabilitas yang dimiliki saat ini sudah tidak memadai lagi untuk mengantisipasi berbagai jenis dan modus kejahatan tersebut.

Seperti halnya jenis kejahatan dan modus operandi yang kian canggih menghendaki aparat intelijen segera menyesuaikan kapasitas kelembagaan dan personal. Sebut saja terorisme, illegal logging, money laundring dan cyber crime. Selama ini tampak bahwa kinerja satuan- satuan intelijen belum dapat memberikan kontribusi yang optimal dalam mendukung misi organisasi. Intelijen Kejaksaan merupakan bagian dari lembaga intelijen negara yang antara lain melakukan penyelidikan awal terhadap dugaan adanya tindak pidana korupsi. Jajaran intelijen pula yang akan menjadi clearing house terhadap barang-barang cetakan atau ajaran yang dianggap membahayakan negara. 


\section{Intelijen Kejaksaan Dalam Perspektif Ketatanegaraan Islam}

Pada zaman pemerintahan Nabi Muhammad saw., tergambar beliau sebagai seorang ahli strategi perang sudah memikirkan pentingnya peran seorang intelijen untuk menghadapi musuh yang menugaskan para intelijennya untuk memata-matai gerakan musuh dan orang-orang yang dianggap munafik. Para agen intelijen Rasulullah juga wajib memegang teguh daftar nama-nama orang munafik itu. Daftar nama mereka harus dihafal, tidak boleh dicatat dan tidak boleh jatuh ke tangan orang lain agar tidak menimbulkan keresahan.

Rasulullah dalam memilih para agen intelijen menilainya dari kemampuan pribadi seseorang terutama dalam menyimpan rahasia. Oleh karena itu, Rasulullah menerapkan sistem satu pintu untuk menyampaikan laporan dari hasil operasi intelijen para spionnya. Dengan sistem itu, para spion langsung menyampaikan laporannya pada Rasulullah Saw dan tidak boleh diketahui oleh orang lain, bahkan oleh para sahabat Rasulullah sendiri yang termasuk dalam Khulafaur Rashidin.

Sejarah Islam tercatat nama Hudzaifah Ibnul Yaman sebagai salah satu agen intelijen atau spion andalan Rasulullah dalam menghadapi orang-orang kafir dan munafik yang ingin memerangi Islam dan Muslim. Oleh Rasulullah, Ibnul Yaman dinilai sebagai orang yang bisa dipercaya, memiliki ingatan yang kuat cerdik dan cerdas dalam mengolah informasi. Ibnul Yaman juga dikenal sosok yang mudah bergaul yang memudahkannya untuk menjalankan operasi mata-mata. ${ }^{29}$ Peran intelijen dalam sejarah islam memiliki arti yang sangat penting. Selain sebagai antisipasi

\footnotetext{
${ }^{29}$ Dalam Perang Khandaq (Perang Parit), Rasulullah menugaskan Ibnul Yaman untuk mematamatai pasukan kafir Quraisy. Rasulullah menerapkan strategi bertahan dengan membuat parit di sekeliling kota Madinah. Pada suatu malam, Rasulullah mengutus Hudzaifah Ibnul Yaman untuk menyusup ke tengah pasukan lawan. Di pihak pasukan lawan, ada kebiasaan yang dilakukan setiap rapat. Sebelum rapat, orang-orang yang hadir harus memastikan bahwa orang-orang di sekelilingnya adalah teman dengan menanyakan nama dan asal-usulnya untuk memastikan bahwa pertemuan mereka aman. Agar penyamarannya tidak terbongkar, Hudzaifah selalu lebih dulu mencekal tangan orang di sebelahnya dan bertanya "siapa namamu?, darimana asalmu?" Orang yang ditanya akan terkejut karena mengira posisi Hudzaifah pasti salah satu pimpinan tertinggi sehingga bertanya lebih dulu. Orang yang ditanyapun langsung menyebutkan nama serta asalnya. Hudzaifah pun selamat dan bisa mengikuti rapat serta mendapatkan informasi penting dari hasil rapat tersebut. Salah satunya, informasi bahwa pasukan Abu Sufyan akan mundur karena merasa pasukannya tidak akan memenangkan pertempuran melawan Rasulullah dan pasukannya di kota Madinah. Lihat Syaikh Mahmud Syakir, Ensiklopedi Peperangan Rasullalah saw. (Jakarta: Pustaka Al-Kausar, 2005), 174.
} 
menghadang serangan lawan, intelijen bermanfaat untuk memberikan keamanan dan keselamatan untuk kehidupan manusia. Dengan memfungsikan cara kerja intelijen dapat meminimalisir segala bentuk niat atau perbuatan jahat yang dilakukan oleh orang-orang yang tidak bertanggungjawab. Sebab dalam alquran sudah digambarkan oleh Allah swt. melalui firman-Nya:

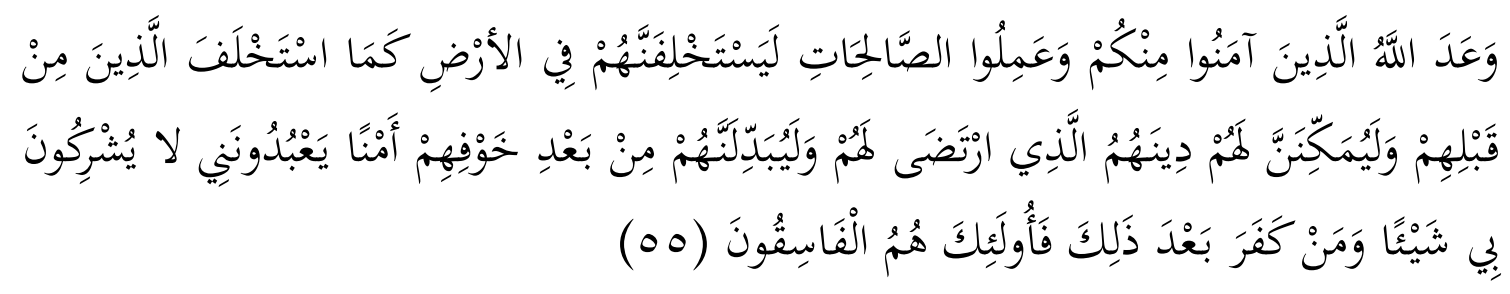

Terjemahnya:

Allah telah menjanjikan kepada orang-orang di antara kamu yang beriman dan yang mengerjakan kebajikan, bahwa Dia sungguh akan menjadikan mereka berkuasa di bumi, sebagaimana Dia telah menjadikan orang-orang sebelum mereka berkuasa, dan sungguh Dia akan meneguhkan bagi mereka dengan agama yang telah Dia ridai. Dan Dia benar-benar mengubah (keadaan) mereka setelah berada dalam katakutan menjadi aman sentosa. Mereka (tetap) menyembahku-Ku dengan tidak mempersekutukan-Ku dengan sesuatu pun. Tetapi barangsiapa (tetap) kafir setelah (janji) itu, maka mereka itulah orang-orang yang fasik (QS. al-Nūr/24: $55) .{ }^{30}$

Mencermati firman Allah swt. tersebut mengandung pesan bahwa kekuasaan harus memberikan jaminan perlindungan terhadap keamanan dan keselamatan kehidupan manusia. Perlindungan terhadap keamanan dan keselamatan bangsa dari ancaman bangsa lain sebagai wujud nyata dari hadirnya sebuah negara dalam melindungi rakyatnya secara komprehensif.

Jika menyisir sejarah pada masa Rasulullah saw., secara garis besar satuan intelijen pada masanya dapat di bagi menjadi dua, yaitu: Pertama, intelijen pengintaian (mata-mata). Intelijen pengintaian merupakan satuan kecil (terdiri dari 20 orang atau kurang) yang ditunjuk khusus oleh Rasulullah saw. untuk menemukan informasi tentang pasukan musuh, perlengkapan senjata, gerakannnya dan rencananya. Informasi tersebut diperlukan sebagai bahan yang akan dianalisa dan hasilnya menjadi bahan pertimbangan dalam menentukan bagaimana, di mana, dan kapan harus melancarkan

\footnotetext{
${ }^{30}$ Kementerian Agama RI., Ummul Mukminin, 357.
} 
operasi militer terhadap musuh. Kemudian, intelijen pengintaian pada masa Nabi saw. dapat dibedakan pula menjadi dua, yaitu: (1) intelijen pengintai yang tidak dipersenjatai, yaitu intelijen yang hanya mempunyai tugas mengumpulkan informasi tentang musuh, tidak terlibat dalam pertempuran, sehingga dalam operasinya dilaksanakan dengan cepat dan sesegara mungkin tanpa terlibat dalam pertempuran; (2) intelijen pengintai yang dipersenjatai yang mempunyai tugas memantau dan mengawasi gerakan musuh, memeriksa tindakan permusuhan, atau mengawal daerah yang tak bertuan atau batas negara. Satuan intelijen tersebut boleh terlibat dalam pertempuran; Kedua, intelijen tempur. Satuan intelijen tempur lebih besar bila dibandingkan dengan intelijen pengintai, yaitu sekitar 15-30 orang. Dinamakan intelijen tempur karena selain mendapat tugas mengumpulkan informasi tentang musuh juga diperintahkan untuk melakukan pertempuran dengan pasukan musuh demi tercapanya tujuan. Tujuan intelijen tempur pada masa Rasulullah saw., selain menjalankan tugas kontra intelijen dengan menjaga perbatasan negara terhadap penyusupan musuh, juga menjalankan fungsi sabotase dengan menutup sumber logistik dan persediaan musuh serta melibatkan musuh dalam pertempuran selagi musuh belum dapat menyiapkan diri dengan baik untuk berperang. Dua jenis sistem operasi intelijen membantu membentuk suatu sistem komunikasi yang kuat, yang dapat memberi informasi pada Nabi saw. tentang segala kejadian pada suku dan daerah perbatasan di sekitar Madinah. Selain mengadakan pos pengintai, Nabi saw juga secara rutin melatih intelijen Islam dengan ilmu militer, isyarat rahasia dan pesan rahasia. ${ }^{31}$

Intelijen merupakan sinonim dari tajassus, yang berarti mengorek-orek suatu berita. Suatu aktivitas dapat digolongkan sebagai perbuatan tajassus (spionase) jika didalamnya ada unsur mencari-cari berita, baik berupa berita rahasia maupun berita umum, namun apabila suatu berita bisa didapatkan secara alami tanpa perlu mengorekorek (tafahhahu) atau tanpa memerlukan aktivitas tajassus, misalnya hanya sekedar mengumpulkan, menyebarkan dan menganalisa suatu berita maka tidak termasuk ke dalam kategori perbutan tajassus (spionase), seperti redaktur koran atau wakil-wakil kantor berita. Namun apabila profesinya digunakan sebagai media melakukan tajassus,

\footnotetext{
${ }^{31}$ Afzalur Rahman, Nabi Muhammad sebagai Seorang Pemimpin Militer (Jakarta: Amzah, 2006), 120-126.
} 
maka orang tersebut disebut jassus (mata-mata). Orang tersebut disebut mata-mata, bukan karena posisinya sebagai redaktur koran yang mencari berita, akan tetapi karena aktivitas mata-mata yang dilakukan dengan menyeru sebagai wartawan sudah masuk kategori aktivitas sponase (tajassus). ${ }^{32}$

Salah satu sumbangan terbesar Rasulullah saw. dalam peradaban manusia, khususnya bidang intelijen Islam adalah saat beliau berperan sebagai Kepala Negara, sekaligus pemimpin perang dengan segala strateginya. Meski begitu, Rasulullah tetap memberikan catatan tersendiri dalam melakukan aktivitas tajassus ini, yaitu: Pertama, posisi intelijen harus di bawah komando pemimpin/komandan perang (jika dalam keadaan perang). Dalam hal ini Rasulullah saw. menerapkan pendidikan kedisiplinan individu agar tidak menimbulkan kekacauan; Kedua, seorang intelijen harus menepati janji. Artinya, seorang intelijen harus amanah, memberikan informasi secara kontinyu dan tidak membocorkan rahasia Negara; Ketiga, seorang intelijen harus menghargai warga sipil. Ini adalah salah satu bukti, dimana Rasulullah saw. sangat menghargai Hak Asasi Manusia (HAM). Orang-orang yang netral seperti warga sipil, oleh beliau tidak masuk dalam daftar orang yang harus dicurigai; dan Keempat, dalam melakukan aktivitas tajassus, seorang Intelijen juga tidak diperbolehkan melanngar pakta perjanjian damai yang telah disepakati. ${ }^{33}$

Intelijen dalam hukum Islam adalah orang yang sedang melakukan tugas juga dilindungi dengan hukum jinayah. Artinya, hukuman terhadap intelijen dihapuskan karena melaksanakan kewajiban bagi pihak yang berwajib (Kepala Negara), untuk menjamin keamanan dan keselamatan Negara. ${ }^{34}$ Pembelaan hukum dalam hal ini sebagai alasan pembenaran (mahkum fih) karena berdasarkan kepentingan umum, amar ma'ruf nahi munkar. Hal ini berdasarkan firman Allah swt. dalam Alquran:

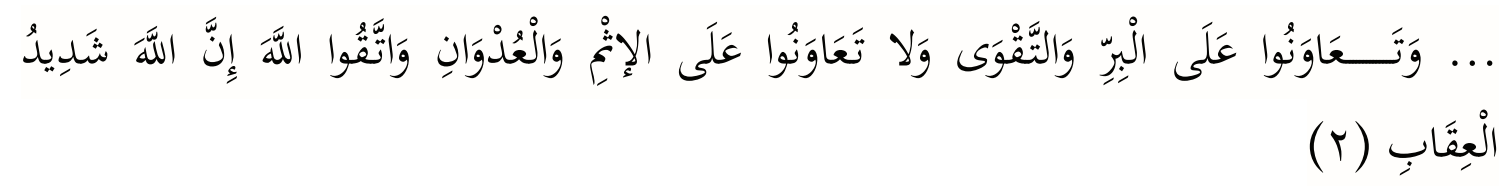

\footnotetext{
${ }^{32}$ Fauzan al-Anshari, Awas Operasi Intelijen (Tangerang: Ar-Rahman Media, 2006), 203-204.

${ }^{33}$ Abi Dawud Sulaiman bin Asy'at al-Sajistani al-Azdari, Sunan Abi Dawud, Jilid 4 (Kairo: Dar El-Hadits, t.th.), 274.

${ }^{34}$ Ahmad Hanafi, Asas-asas Hukum Pidana Islam (Jakarta: Bulan Bintang, 2005), 164.
} 
Terjemahnya:

...Dan tolong-menolonglah kamu dalam (mengerjakan) kebajikan dan takwa, dan jangan tolong-menolong dalam berbuat dosa dan permusuhan. Bertakwalah kepada Allah, sungguh Allah sangat berat siksa-Nya (QS. al-Maidah/5: 2). ${ }^{35}$

Berdasarkan kandungan ayat QS al-Maidah/5: 2, maka hukum melakukan aktivitas intelijen Negara dalam Islam mendapatkan pengakuan, sepanjang itu dijalankan pada ranah kebaikan dan kemaslahatan umat. Ajaran Islam mengenal adsanya amar ma'ruf nahi munkar yang merupakan kewajiban yang tidak boleh ditinggalkan. Pengakuan ini mendorong manusia untuk menjadi teladan kepada sesama agar berdiri atas dasar hukum dan tidak melanggarnya. Apabila cara kerja intelijen kejaksaan melebihi dari kewenangannya, maka hal tersebut harus dijatuhkan sanksi hukum.

Kesewenang-wenangan aparat intelijen kejaksaan tidak dapat dibenarkan dalam bangunan negara hukum Indonesia apabila sudah mengatasnamakan Negara, tetapi kemudian melanggar hukum negara dan hak asasi manusia. Sebaliknya juga bahwa dalam kerja-kerja intelijen kejaksaan digunakan untuk mencegah dan menangkal segala potensi kejahatan yang akan dilakukan, maka demi kemaslahatan umat intelijen kejaksaan dapat melakukan penindakan sesuai prosedur hukum yang berlaku. Melihat kegiatan intelijen yang meliputi penyelidikan, pengamanan dan penggalangan, bukan tidak mungkin muncul kesalahan prosedur dalam menjalankan aktivitas intelijen. Dengan kata lain, bahwa melakukan kegiatan intelijen harus penuh kehati-hatian dengan mengedepankan profesionalisme yang mana setiap melakukan penyelidikan, pengamanan atau penggalangan, dua fungsi intelijen lainnya harus merupakan kesatuan fungsi yang saling menunjang, sehingga didapatkan keterpaduan penyelenggaraan kegiatan intelijen. Penyelidikan harus melakukan tindakan pengamanan dan melakukan penggalangan bila diperlukan. Selanjutnya dalam melakukan pengamanan, juga harus melakukan penyelidikan dan penggalangan. Demikian pula bila melakukan penggalangan, melakukan penyelidikan dan pengamanan. Bagi insan intelijen yang profesional, fungsi intelijen adalah merupakan naluri intelijen yang harus dihayati dan diterapkan secara terampil dan profesional. Oleh sebab itu, intelijen kejaksaan

\footnotetext{
${ }^{35}$ Kementerian Agama RI., Ummul Mukminin, 106.
} 
dibutuhkan untuk mencegah tindak kejahatan yang mengacam kelangsungan hidup dan harta benda masyarakat. Intelijen juga dibutuhkan untuk mencegah terjadinya ancaman terhadap keamanan nasional yang dilakukan aktor-aktor domestik yang ingin menjatuhkan merusak tatanan kehidupan berbangsa dan bernegara.

\section{E. Kesimpulan}

Sejarah Islam telah mencatat bahwa peran intelijen menjadi faktor penting dalam pergerakan untuk mempertahankan kejayaan islam yang dipimpin oleh Rasulullah saw. untuk melawan musuh islam. Aktivitas intelijen mendapatkan pengakuan dari kandungan beberapa ayat dalam Alquran sebagai jalan untuk bagaimana mengamalkan amar ma'ruf nahi munkar. Aktivitas intelijen kejaksaan sebagai penyelenggara intelijen negara memiliki peran penting dalam menjaga keamanan dan ketertiban negara dalam kelompok/individu yang ingin merusak tatanan kehidupan berbangsa dan bernegara. Intelijen kejaksaan sebagai organ negara yang berada di bawah institusi Kejaksaan RI mesti dilakukan pembenahan dari sisi yuridisnya yang mana perlu pengaturan secara jelas dalam undang-undang Kejaksaan RI sehingga intelijen kejaksaan dalam sistem ketatanegaraan indonesia mampu bekerja dengan instrumen hukum yang jelas dan tidak akan menimbulkan disorientasi terhadap kinerja intelijen kejaksaan.

\section{Daftar Pustaka}

Anshari, Fauzan. Awas Operasi Intelijen. Tangerang: Ar-Rahman Media, 2006.

Al-Azdari, Abi Dawud Sulaiman bin Asy'at al-Sajistani. Sunan Abi Dawud, Jilid 4. Kairo: Dar El-Hadits, t.th.

Bhakti Ikrar Nusa, dan Diandra Megaputri Mengko, "Intelijen Dalam Pusaran Demokrasi Di Indonesia Pasca Orde Baru," Jurnal Penelitian Politik, Volume 13 No. 1 Juni 2016.

Bhakti, Ikrar Nusa. Intelijen dan Keamanan Negara: Reformasi Intelijen Negara. Jakarta: Pacivis UI dan FES, 2005.

Hanafi, Ahmad. Asas-asas Hukum Pidana Islam. Jakarta: Bulan Bintang, 2005. 
Hendropriyono, A. M. Filsafat Intelijen Negara Republik Indonesia. Jakarta: PT Kompas Media Nusantara, 2013.

Hutagaol, Togar. Administrasi dan Produk Intelijen Kejaksaan. Jakarta: Pusdiklat Kejaksaan Republik Indonesia, 2006.

Iskandar, Nandan, et.al, Penguatan Peran Intelijen Kejaksaan Dalam Pengawasan Aliran Kepercayaan dan Aliran Keagamaan Dalam Masyarakat (PAKEM) Demi Ketertiban dan Ketenteraman Umum. Jakarta: Kejaksaan Agung, Pusat Penelitian dan Pengembangan, 2017.

Kelompok Kerja Indonesia, Rancangan Undang-Undang Intelijen Negara. Jakarta. Pacivis Departemen Hubungan Internasional, Fakultas Ilmu Sosial dan Politik, Universitas Indonesia, 2005.

Kementerian Agama RI. Ummul Mukminin: Al-Qur'an dan Terjemahan untuk Wanita. Jakarta: Penerbit Wali, 2010.

Manulang, A. C. Menguak Tabu Intelijen, Teror, Motif, dan Rezim. Cet. I; Jakarta: Penerbit Panta Rhei, 2000.

Marpaung, Leden. Proses Penanganan Perkara Pidana (Di Kejaksaan \&Pengadilan Negeri Upaya Hukum dan Eksekusi). Jakarta, Sinar Grafika, 2011.

Prajogo, Soesilo. Kamus Hukum Internasional dan Indonesia. T.tp: Wacana Inteletual, 2007.

Rahman, Afzalur. Nabi Muhammad sebagai Seorang Pemimpin Militer. Jakarta: Amzah, 2006.

Republik Indonesia, Peraturan Jaksa Agung Republik Indonesia Nomor: Per006/A/JA/07/2017 tentang Organisasi dan Tata Kerja Kejaksaan Republik Indonesia.

Republik Indonesia, Undang-Undang Dasar Negara Republik Indonesia Tahun 1945 Pasca Amandemen.

Republik Indonesia, Undang-Undang Nomor 17 Tahun 2011 tentang Intelijen Negara.

Republik Indonesia. Undang-Undang Nomor 16 Tahun 2004 tentang Kejaksaan Republik Indonesia.

Republik Indonesia. Undang-Undang Nomor 16 Tahun 2004 tentang Kejaksaan Republik Indonesia.

Syakir, Syaikh Mahmud. Ensiklopedi Peperangan Rasullalah saw. Jakarta: Pustaka AlKausar, 2005. 
Wibisono Ali Abdullah, dan Faisal Idris, Menguak Intelijen "Hitam" Indonesia. Jakarta: Pacivis University of Indonesia, 2006.

Wibisono, Ali Abdullah. Reformasi Intelijen dan Badan Intelijen Negara. Jakarta: IDSPS Press, 2009.

Wojowasito, S. dan W. J. S. Poerwadarminta, Kamus Bahasa Inggris Indonesia. Hasta: Bandung, 2007.

http://lama.elsam.or.id

https://id.wikipedia.org/wiki/Pemeluk_Islam_pertama

https://www.arrahmah.com/konsep-intelijen-rasulullah/

https://www.republika.co.id/berita/dunia-islam/islam-digest/18/02/26/p4quuz313operasi-intelijen-rasulullah 